\title{
Nadir Bir Bakteriyemi Etkeni: Granulicatella adiacens
}

\author{
A Rare Cause of Bacteremia: Granulicatella adiacens
}

\section{A.Hande Türk, Ebru Evren, Ebru Us, Z.Ceren Karahan}

Ankara Üniversitesi Tıp Fakültesi, Tıbbi Mikrobiyoloji Anabilim Dalı ve Ibni Sina Eğitim ve Araştırma Hastanesi Merkez Mikrobiyoloji Laboratuvarı, Ankara, Türkiye

\section{ÖZET}

Granulicatella adiacens, oral, ürogenital ve gastrointestinal florada bulunan, nadiren enfeksiyon etkeni olarak saptanan bir bakteridir. Çoğunlukla immündüşkün hastalarda enfeksiyon oluşturmaktadır. Rutin kültürlerde zor ve yavaş üremesi izolasyonunu zorlaştırmaktadır. Bu makalede, G.adiacens bakteriyemili bir olgu sunulmuştur.

Anahtar Sözcükler: Granulicatella adiacens, bakteriyemi

Geliş Tarihi: 16.07.2019

Kabul Tarihi: 18.11.2019

\section{ABSTRACT}

Granulicatella adiacens is a commensal of oral, urogenital and gastrointestinal flora which rarely causes infection. It mostly causes infections in immunosuppressed patients. Isolation of this bacteria is difficult due to its fastidious nature and slow growth on routine cultures. Here we report a patient with bacteremia caused by G.adiacens.

Key Words: Granulicatella adiacens, bacteremia

Received: 07.16 .2019

Accepted: 11.18 .2019

\section{GiRiş}

Granulicatella adiacens, insanlarda; oral, ürogenital ve gastrointestinal sistemin flora elemanıdır (1-4). Nazlı üreyen bu gram-pozitif kok, 1961'de 'nütrisyonel varyant streptokok' olarak tanımlanmış, 16S rRNA dizi analizi sonucunda Streptococcus cinsinden ayrılarak Abiotrophia cinsine alınmıştır. 2000'de Abiotrophia cinsinin gruplara ayrılmasıyla Granulicatella adını almıştır. G.adiacens ve G.elegans bu cinsin insandan izole edilen türleridir (13).

Granulicatella türleri nadiren enfeksiyona yol açar. Çoğunlukla immündüşkün hastalarda enfektif endokardit $(E E)$ ve bakteriyemi etkeni olarak saptanır (5).

\section{OLGU SUNUMU}

Temmuz 2018'de, 78 yaşındaki kadın hasta, iki gündür devam eden halsizlik ve anüri nedeniyle acil servise başvurmuştur. Hipertansiyon, diyabetes mellitus ve kronik böbrek yetmezliği (KBY) tanıları ile izlenen hastanın 1995'te tiroidektomi geçirdiği, 2011'de kolon kanseri tanısıyla opere olduğu, 2014'te akut miyokard infarktüsü sonrası gelişen kronik kalp yetmezliği ve 2015'te Alzheimer hastalığı tanısı konduğu öğrenilmiştir. Obez görünümdeki hastanın muayenesinde bacaklarda pretibial ödem ve akciğer bazallerinde kaba raller saptanmıştır. 
Laboratuvar testlerinde, kan glukozu $160 \mathrm{mg} / \mathrm{dl}[74-100 \mathrm{mg} / \mathrm{dl}]$, kan üre azotu $96 \mathrm{mg} / \mathrm{dl}$ [8-23mg/dl], glomerüler filtrasyon hızı $4 \mathrm{ml} / \mathrm{dk} / 1,73 \mathrm{~m}^{2}$ [>60ml/dk/1,73m²], kreatinin $7,81 \mathrm{mg} / \mathrm{dl}[0,51-0,95 \mathrm{mg} / \mathrm{dl}]$, kalsiyum $7,8 \mathrm{mg} / \mathrm{dl}$ $[8,8-10,6 \mathrm{mg} / \mathrm{dl})]$, fosfor $7,3 \mathrm{mg} / \mathrm{dl}[2,5-4,5 \mathrm{mg} / \mathrm{dl}]$, albumin $2,8 \mathrm{~g} / \mathrm{dl}[3,5-5,2$ $\mathrm{g} / \mathrm{dl}]$, C-reaktif protein (CRP) $63 \mathrm{mg} / \mathrm{l}[0-5 \mathrm{mg} / \mathrm{l}]$, lökosit sayıs 10,2×109\%/ [4,5$\left.11 \times 10^{9} / I\right]$ eritrosit sayısI $2,40 \times 10^{12} / / \quad\left[3,8-5,2 \times 10^{12} / l\right]$, hemoglobin konsantrasyonu $6,9 \mathrm{~g} / \mathrm{dl}\left[11,7-16,1 \times 10^{12} / \mathrm{l}\right]$ bulunmuştur.

KBY zemininde gelişen akut böbrek yetmezliği tanısı konan hastaya iki ünite eritrosit süspansiyonu verilmiş, santral venöz kateter (SVK) takılarak hemodiyaliz uygulanmak üzere nefroloji servisine yatırılmıştır.

Yatışının 15. gününde genel durumu bozulan, oksijen ihtiyacı başlayan, ateşi $38,4^{\circ} \mathrm{C}^{\prime}$ ye yükselen hastada CRP $265,4 \mathrm{mg} / \mathrm{l}$, prokalsitonin $0,45 \mathrm{ng} / \mathrm{dl}[0,12-0,5$ $\mathrm{ng} / \mathrm{dl}=$ düşük sepsis riski], lökosit sayısı 12,66×10\%/l (\%66 nötrofil) bulunmuş, enfeksiyon düşünülerek her iki kol ve SVK'dan, her biri bir aerobik ve bir anaerobik (BACTEC Plus Aerobic ve BACTEC Lytic Anaerobic, Becton Dickinson, $A B D)$ şişeden oluşan üç set kan kültürü alınarak piperasilin tazobaktam ve teikoplanin başlanmıştır.

Otomatize kan kültür cihazında (BD BACTEC FX, Becton Dickinson, ABD) inkübasyona alınan altı şişenin hepsinde 16-23. saatlerde üreme olmuş, hazırlanan Gram boyalı preparatlarda zincir yapmış gram-pozitif koklar görülmüştür. Şişelerden, Streptococcus spp. düşünülerek \%5 koyun kanlı agara (KKA) yapılan ve normal atmosfer şartlarında inkübe edilen pasajlarda ertesi gün üreme gözlenmemesi üzerine plakların inkübasyonu uzatılmış ve şişelerden çikolata agara (ÇA) pasaj alınmıştır. ÇA plakları $\% 5 \mathrm{CO}_{2}^{\prime}$ li ortamda, $37^{\circ} \mathrm{C}^{\prime}$ de inkübe edilmiş, ertesi gün sadece ÇA plaklarında üreme gözlenmiştir $(\operatorname{Resim} 1)$.

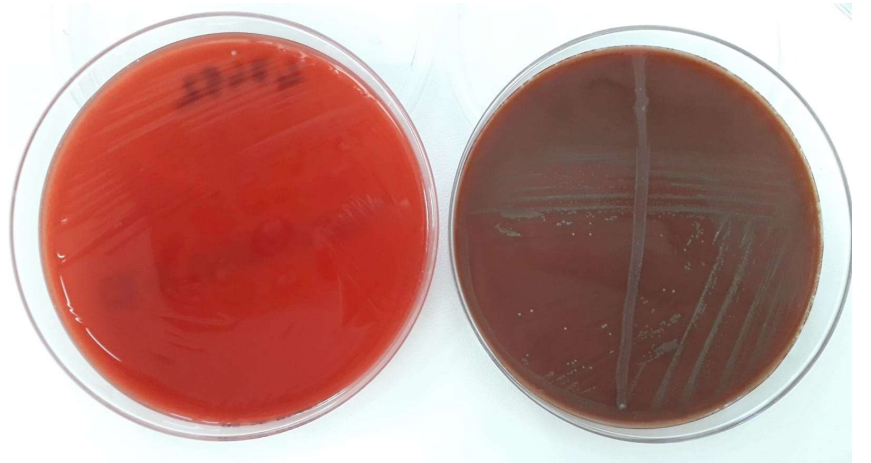

Resim 1. Kan kültürü şişesinden yapılan pasajlarda çikolata agarda üreyen $G$. adiacens kolonileri

Kolonilerden G.adiacens tanımlaması, matriks ile desteklenmiş lazer dezorpsiyon iyonizasyon-uçuş zamanı kütle spektrometrisi (MALDI-TOF MS, Bruker Daltonics, Bremen, Almanya) ile yapılmıştır. Antimikrobiyal duyarlılık testi (ADT), gradyent test şeritleri (BioMerieux, Fransa) kullanılarak gerçekleştirilmiş, tespit edilen minimum inhibitor konsantrasyon (MiK) değerleri, EUCAST önerileri doğrultusunda, farmakokinetik/farmakodinamik eşik değerler dikkate alınarak yorumlanmıştır (6). İzolat; ampisilin, penisilin, sefepim, sefuroksim, sefotaksim ve teikoplanine dirençli; imipenem (MiK=0,047 $\mu \mathrm{g} / \mathrm{ml}$ ), meropenem (MiK=0,064 $\mu \mathrm{g} / \mathrm{ml}$ ) ve vankomisine duyarlı (MiK=2 $\mu \mathrm{g} / \mathrm{ml}$ ) bulunmuştur.

ADT sonucuna göre hastaya meropenem başlanmış, SVK çıkartılmıştır. Enfeksiyon bulguları gerileyen, genel durumu düzelen hastada 17. günde antibiyotik tedavisi kesilmiş, komorbid hastalıkları açısından tedavisi düzenlenerek yatışının 38. gününde taburcu edilmiştir.

\section{TARTIŞMA}

Granulicatella türleri flora elemanı olmakla birlikte, immün-düşkün hastalarda enfeksiyona neden olabilir (5). Diş plak ve apselerinde bulunabilir ve yakın dönemde yapılan diş tedavisi bir risk faktörü olabilir $(4,7)$. Menenjit, osteomiyelit, peritonit, pnömoni, yabancı cisim enfeksiyonlarında etken olarak tanımlanmışsa da sıklıkla EE ve bakteriyemi etkeni olarak izole edilir. Tüm EE'lerin \%4,3-6'sında etkenin Granulicatella ve Abiotrophia türleri olduğu düşünülmektedir $(1,8)$. Granulicatella endokarditinde relaps riski ve mortalitenin yüksekliğine $(\% 9,5)$ ve tanımlanmasındaki zorluk nedeniyle atlandığına dikkat çekilmiştir $(3,5)$.

Granulicatella türleri mikroskopide çiftler halinde, zincir yapan gram pozitif kok veya pleomorfik yapıda görülebilir. Kan kültürü vasatlarında ve çikolata agar gibi piridoksal içeren besiyerlerinde, aerobik ve anaerobik ortamda, 37 ? $C^{\prime}$ de ürer.
Kanlı agarda ancak Staphylococcus aureus kolonileri çevresinde uydu koloniler oluşturarak üreyebilir $(1,3)$. Biyokimyasal testlerle tanımlanması zordur. Tanımlamada altın standart 16S rRNA dizi analizidir. MALDI-TOF MS ile bu bakterinin tanımlanması kolaylaşmıştır (9).

Granulicatella'da beta-laktamlara direnç sıktır (2). Klindamisin, tetrasiklin, eritromisin, siprofloksasine direnç bildirilmiştir. Vankomisin ve rifampisin direnci bildirilmemiştir. Mustaq ve ark.'nın (10), çalışmasında izolatların duyarlılıkları vankomisine $\% 100$, meropeneme \%87, penisiline $\% 34$, seftriaksona $\% 22$, sefotaksime $\% 10$, sefepime $\% 3$ olarak bulunmuş, klinik önemi olan tüm izolatlarda rutin ADT yapılması önerilmiştir.

\section{SONUÇ}

G.adiacens özellikle immün-düşkün hastalarda enfeksiyon etkeni olabilir. Üreme sinyali alınan kan kültürü şişelerinde gram-pozitif kok görülmesine rağmen pasajlarda üreme olmadığında veya zayıf üreyen alfa-hemolitik streptokoklarla karşılaşıldığında düşünülmesi, uygun besiyeri-inkübasyon koşulları sağlanarak üretilmesi gerekir. MALDI-TOF MS ve moleküler yöntemlerle tanımlanma şansı yüksektir. Direnç sorunu nedeniyle hastaların tedavi planlanmasıda ADT sonuçları dikkate alınmalıdır.

\section{Çıkar Çatışması}

Yazarlar herhangi bir çıkar çatışması bildirmemiştir.

\section{KAYNAKLAR}

1. Gardenier JC, Hranjec T, Sawyer RG, Bonatti H. Granulicatella adiacens bacteremia in an elderly trauma patient. Surg Infect (Larchmt). 2011;12(3):251-253.

2. Zheng $X$, Freeman $A F$, Villafranca J, Shortridge $D$, Beyer J, Kabat $W$ et al. Antimicrobial susceptibilities of invasive pediatric Abiotrophia and Granulicatella isolates. J Clin Microbiol. 2004;42(9):4323-4326.

3. Cargill JS, Scott KS, Gascoyne-Binzi D, Sandoe JAT. Granulicatella infection diagnosis and management. J Med Microbiol. 2012;61(6):755-761.

4. Aas JA, Paster BJ, Stokes LN, Olsen I, Dewhirst FE. Defining the norma bacterial flora of the oral cavity. J Clin Microbiol, 2005;43(11):5721-5732.

5. Christensen JJ, Facklam RR. Granulicatella and AbiotrophiaSpecies from Human Clinical Specimens. J Clin Microbiol, 2001;39(10):3520-3523.

6. The European Committee on Antimicrobial Susceptibility Testing. Breakpoint tables for interpretation of MICs and zone diameters. Version 8.1, 2018. http://www.eucast.org.

7. Mougari F, Jacquier H, Bercot B, Hannouche D, Nizard R, Cambau E et al. Prosthetic knee arthritis due to Granulicatella adiacens after dental treatment. J Med Microbiol, 2013;62(10):1624-1627.

8. Broqui $P$, Raoult $D$. Endocarditis due to rare and fastidious bacteria. Clin Microbiol Rev. 2001;14(1):177-207.

9. Woo PCY, Fung AMY, Lau SKP, Chan BYL, Chiu SK, Teng JLL et al. Granulicatella adiacens and Abiotrophia defectiva bacteraemia characterized by $16 \mathrm{~S}$ rRNA gene sequencing. J Med Microbiol. 2003;52(2):137-140.

10. Mushtaq A, Greenwood-Quaintance KE, Cole NC, Kohner PC, Ihde SM, Strand GJ et al. Differential antimicrobial susceptibilities of Granulicatella adiacens and Abiotrophia defectiva. Antimicrob Agents Chemother. 2016;60(8):5036-5039. 